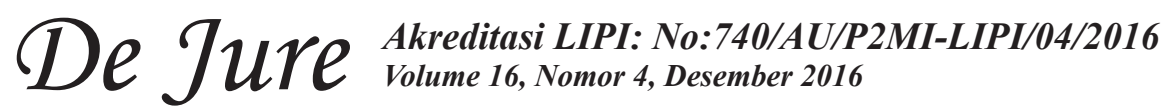

Jurnal Penelitian Hukum De Jure adalah majalah hukum triwulan (Maret, Juni, September dan Desember) diterbitkan oleh Badan Penelitian dan Pengembangan Hukum dan HAM Kementerian Hukum dan HAM RI bekerjasama dengan IKATAN PENELITI HUKUM INDONESIA (IPHI) Pengesahan Badan Hukum Perkumpulan Keputusan Menteri Hukum dan Hak Asasi Manusia Nomor : AHU-13.AHA.01.07 Tahun 2013, Tanggal 28 Januari 2013, bertujuan sebagai wadah dan media komunikasi, serta sarana untuk mempublikasikan aneka permasalahan hukum yang aktual dan terkini bagi para peneliti hukum Indonesia khususnya dan kalangan masyarakat pemerhati hukum pada umumnya.

Penanggung Jawab

Y. Ambeg Paramarta, S.H.,M.Si

(Kepala Badan Penelitian dan Pengembangan Hukum dan Hak Asasi Manusia)

\section{Pemimpin Umum}

Marulak Pardede, S.H.,M.H.,APU

(Ketua Ikatan Peneliti Hukum Indonesia)

\section{Wakil Pemimpin Umum}

T. Daniel L. Tobing, S.H

(Kepala Pusat Pengembangan Data dan Informasi Peneliti Hukum dan Hak Asasi Manusia)

DR. Agus Anwar, S.H.,M.H

(Kepala Pusat Penelitian dan Pengembangan Hukum)

Pemimpin Redaksi

Akhyar Ari Gayo, S.H.,M.H.,APU (Hukum Islam, BALITBANGKUMHAM)

\section{Anggota DewanRedaksi}

DR. Ahmad Ubbe, S.H.,M.H., APU (Hukum Adat, BALITBANGKUMHAM)

Mosgan Situmorang, S.H.,M.H (Hukum Perdata, BALITBANGKUMHAM)

Syprianus Aristieus, S.H.,M.H (Hukum Perusahaan, BALITBANGKUMHAM)

Nevey Varida Ariani, S.H.,M.H (Hukum Pidana, BALITBANGKUMHAM)

Eko Noer Kristiyanto, S.H (Hukum Perdata, BALITBANGKUMHAM)

Muhaimin, S.H (Hukum Islam, BALITBANGKUMHAM)

\section{Redaksi Pelaksana}

Yatun, S.Sos

Sekretaris

M. Virsyah Jayadilaga, S.Si.,M.P

Asmadi

\section{Tata Usaha}

Dra. Evi Djuniarti, M.H

Galuh Hadiningrum, S.H

Suwartono 


\section{TUTe $\begin{aligned} & \text { Akreditasi LIPI: No:740/AU/P2MI-LIPI/04/2016 } \\ & \text { Volume 16, Nomor 4, Desember } 2016\end{aligned}$}

Teknologi Informasi dan Desain Layout

Risma Sari, S.Kom., M.Si (Teknologi Informasi)

Machyudhie, S.T (Teknologi Infornasi)

Saefullah, S.ST.,M.Si (Teknplogi Informasi)

Agus Priyatna, S.Kom (Desain Layout)

Teddy Suryotejo

\section{Mitra Bestari}

Prof. DR. Rianto Adi, M.A (Sosilogi Hukum, UNIKA ATMAJAYA JAKARTA)

Prof. DR. Jeane Neltje Saly, S.H.,M.H (Hukum Humaniter, UNIV. 17 Agustus 1945 Jakarta)

Prof. DR. Hibnu Nugroho, S.H (Hukum Fidana, FH. UNSOED)

DR. Farhana, S.H.,M.H (Hukum Pidana, Fak. Hukum Universitas Islam Jakarta)

DR. Ridwan Nurdin, M.A (Hukum Syariah, Fakultas Syariah Univ. Arraniri Banda Aceh)

DR. Hadi Supratikta (Administrasi Pemerintahan, Balitbang Kemendagri)

\section{Alamat Redaksi:}

Gedung Badan Penelitian dan Pengembangan Hukum dan Hak Asasi Manusia

Kementerian Hukum dan Hak Asasi Manusia Republik Indonesia

Jl. HR. Rasuna Said Kav.4-5, Kuningan, Jakarta Selatan

Telepon, (021)2525015, Faksimili (021) 2526438

Email :

jurnaldejure@yahoo.com

balitbangkumham@gmail.com

ejournaldejure@gmail.com

\section{Percetakan}

PT Pohon Cahaya

Jalan Gedung Baru 18 Jakarta Barat 11440

Telpon (021) 5600111, Faksimili (021) 5670340

Redaksi menerima naskah karya asli yang aktual dalam bidang hukum berupa hasil penelitian dari berbagai kalangan, seperti: peneliti hukum, praktisi dan teoritisi, serta berbagai kalangan lainnya. Tulisan-tulisan yang dimuat merupakan pendapat pribadi penulisnya, bukan pendapat redaksi.

Redaksi berhak menolak, menyingkat naskah tulisan sepanjang tidak mengubah isinya. Naskah tulisan dapat dikirim ke alamat redaksi, maksimum 30 halaman A4, diketik spasi dua rangkap dikirim melalui Email: jurnaldejure@yahoo.com atau melalui aplikasi Open Journal System (OJS) pada URL/website: ejournalbalitbangham.go.id 


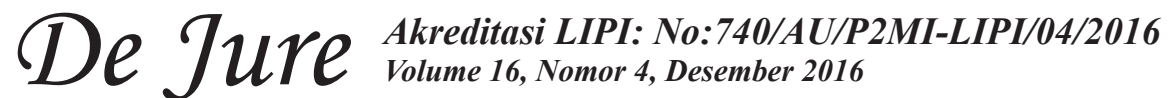

\section{DAFTAR ISI}

\section{DAFTAR ISI}

ADVERTORIAL

Implementasi Konvensi Hak Anak Terkait dengan Perlindungan Anakyang

Berhadapan dengan Proses Hukum

(Implementation of Children Rights

Convention Related to Children Protection Against The Law)

$439-450$

Rosmi Darmi

DAFTAR RIWAYAT HIDUP

$505-506$

PEDOMAN PENULISAN

507- 508 


\section{De TuPe $\begin{aligned} & \text { Akreditasi LIPI: No:740/AU/P2MI-LIPI/04/2016 } \\ & \text { Volume 16, Nomor 4, Desember } 2016\end{aligned}$}

Puji syukur kehadirat Allah SWT, Jurnal Penelitian Hukum De Jure yang diterbitkan Badan Penelitian dan Pengembangan Hukum dan HAM Kementerian Hukum dan Hak Asasi Manusia bekerjasama dengan Ikatan Peneliti Hukum Indonesia dapat menerbitkan Volume 16 Nomor 4, Desember 2016.

Para pembaca Jurnal Penelitian Hukum De Jure yang tercinta, sebagaimana diketahui bahwa pada tanggal 10 Desember setiap tahunnya diperingati sebagai Hari Hak Asasi Manusia sedunia. Tanggal ini dipilih untuk menghormat Majelis Umum PBB yang mengadopsi dan memproklamirkan Deklarasi Universal Hak Asasi Manusia, sebuah pernyataan global tentang hak asasi manusia pada 10 Desember 1948.

Apabila menilik Hukum dan HAM, merupakan konsepsi kemanusiaan dan relasi sosial yang dilahirkan dari sejarah peradaban manusia di seluruh penjuru dunia. Hukum dan HAM juga dapat dimaknai sebagai hasil perjuangan manusia untuk mempertahankan dan mencapai harkat kemanusiaannya. Agar HAM dapat ditegakkan dalam berbagai kehidupan harus ada instrumen yang mengaturnya. Instrumen tersebut berisi aturanaturan bagaimana HAM itu ditegakkan dan mengikat seluruh warganegara. Sebagai negara yang menjunjung tinggi HAM Indonesia telah memiliki setidak-tidaknya empat instrumen HAM, yakni UUD 1945, TAP MPR Nomor XVII/MPR/1998, UU Nomor 39 Tahun 1999 tentang Hak Asasi Manusia.

Dari beberapa intrumen yang ada tersebut berharap perlindungan dan penegakan HAM kedepanya dapat meningkat, karena masih banyak kekurangan-kekurangan yang harus diperbaiki oleh pemerintah. Seperti lebih difungsikan secara maksimal lembaga-lembaga yang memiliki tugas khusus menegakan HAM.

Dalam rangka memperingati Hari Hak Asasi Manusia Sedunia tersebut, Dewan Redaksi mengangkat tuisan-tulisan dari para peneliti di lingkungan Kementerian Hukum dan HAM yang bersinggungan dengan penegakan Hukum dan HAM di Indonesia.

Akhirnya kami menyampaikan ucapan terima kasih kepada Kepala Badan Penelitian dan Pengembangan Hukum dan HAM Kementerian Hukum dan HAM RI dan Ketua Ikatan Peneliti Hukum Indonesia dalam penerbitan buku ini. Dan juga kami ucapkan terima kasih kepada Prof. DR. Rianto Adi, M.A., Prof. DR. Jeane Neltje Saly, S.H.,M.H., Prof. DR. Hibnu Nugroho, S.H., DR. Farhana, S.H., M.H., DR. Ridwan Nurdin, M.A.,dan DR. Hadi Supratikta, Selaku Mitra Bestari yang telah bersedia membantu memeriksa dan mengoreksi tulisan dari para penulils.

Jakarta, Desember 2016 


\title{
IMPLEMENTASI KONVENSI HAK ANAK TERKAIT DENGAN PERLINDUNGAN ANAK YANG BERHADAPAN DENGAN PROSES HUKUM \\ (Implementation of Children Rights Convention Related to Children Protection Against The Law)
}

\author{
Rosmi Darmi \\ Peneliti pada Pusat Penelitian dan Pengembangan Hukum, Badan Penelitian \\ dan Pengembangan Hukum dan Hak Asasi Manusia \\ Kementerian Hukum dan Hak Asasi Manusia Republik Indonesia \\ Jalan HR Rasuna Said Kavling 4 -5, Jakarta Selatan 12920 \\ Telepon (021)2525015 Faksimili (021)2526438 \\ HP: 085669348629 - Email: novi_dpr@yahoo.com \\ Tulsan diterima: 3-10-2016, Direvisi: 9-12-2016; \\ Disetujui diterbitkan: 23-12-2016
}

\begin{abstract}
A number of the child are against the law must become a concern. Besides that, practices of the juvenile justice system pay attention to parties, particularly in a legal proceeding. The problem of this writing is how to implement the Convention of Child Rights (KHA) related to child protection against law proceedings. Its protection refers to the Convention on the Rights of the Child and Beijing Rule. Spelling out of law protection of child offender in the convention have covered largely child protection principle of a legal instrument, nationally and internationally. Child investigation encompasses arrest, inspection, investigation and termination of detention.
\end{abstract}

Keywords: Convention on the Child Rights, child protection

\begin{abstract}
ABSTRAK
Meningkatnya peristiwa Anak yang Berhadapan dengan Hukum (ABH) menimbulkan keprihatinan. Selain itu, penerapan sistem peradilan pidana anak menjadi perhatian banyak pihak, terutama dalam proses hukum. Permasalahan dalam tulisan ini adalah bagaimana implementasi Konvensi Hak Anak (KHA) Terkait denga perlindungan anak yang berhadapan dengan proses hukum. Perlindungan hukum terhadap dalam proses hukum mengacu kepada Konvensi Hak-Hak Anak (Convention on The Rights of The Child) dan Beijing Rule. Penjabaran perlindungan hukum anak pelaku tindak pidana dalam konvensi tersebut telah mencakup sebagian besar prinsip perlindungan anak pelaku tindak pidana baik dalam instrumen hukum nasional maupun instrumen hukum internasional. Pelaksanaan penyidikan terhadap anak pelaku tindak pidana dalam proses penyidikan meliputi tindakan penangkapan, pemeriksaan, penghentian penyidikan dan penahanan.
\end{abstract}

Kata Kunci: Konvensi Hak Anak, Perlindungan Anak

\section{PENDAHULUAN}

Perlindungan anak merupakan suatu upaya untuk menciptakan kondisi dimana anak dapat melaksanakan hak dan kewajibanya. Berdasarkan konsepparents patriae, yaitu negara memberikan perhatian dan perlindungan kepadaanak-anak sebagaimana layaknya orang tua kepada anak-anaknya, maka penanganan anak-anak yang berhadapan dengan hukum juga harus dilakukandemi kepentingan terbaik bagi anak serta berpijak pada nilai-nilai Pancasila
(Rochaeti, 2008:). Oleh karena itu ketentuan mengenai penyelenggaraan pengadilan bagi anak dilakukan secara khusus, hal ini bertujuan untuk mewujudkan penanganan perkara anak yang berhadapan dengan hukum.

Banyaknya kasus anak yang terjadi akhir akhir ini makin meningkatkan keprihatinan. Dalam meminimalisir kasus yang merugikan anak, Berdasarkan data dari Ditjen Pemasyarakatan pada bulan Februari 2014 mengenai jumlah tahanan anak dan napi anak di seluruh provinsi 
di Indonesia, jumlah tahanan anak adalah 1.854 anak, terdiri dari 1.794 tahanan anak laki-laki dan 60 tahanan anak perempuan. Sedangkan jumlah napi anak adalah 3.085 anak, terdiri dari 3.021 napi anak laki-laki dan 64 napi anak. Adapun lima provinsi yang jumlah tahanan anak dan napi anaknya terbanyak adalah Sumatera Utara, Jawa Barat, Sumatera Selatan, DKI Jakarta, dan Jawa Timur.(Ditjen Pemasyarakatan, smslap. ditjenpas.go.id/public/grl/current/montly, diakses tanggal 4 Februari 2014)

Banyaknya peristiwa Anak yang Berhadapan dengan Hukum $(\mathrm{ABH})$ menimbulkan keprihatinan. Terlebih ketika anak-anak tersebut diajukan ke pengadilan atas kejahatan ringan seperti pencurian. Pada umumnya mereka tidak mendapatkan dukungan dari pengacara maupun dinas sosial. Maka tidaklah mengejutkan, sembilan dari sepuluh anak ini akhirnya dijebloskan ke penjara atau rumah tahanan. Yang memprihatinkan, mereka seringkali disatukan dengan orang dewasa karena kurangnya alternatif terhadap hukuman penjara (Purnianti, Mamik Sri Supatmi, Ni Made Martini Tinduk, tanpa tahun : i.)

Ketika berhadapan dengan kasus hukum baik dalam posisi sebagai pelaku, saksi, maupun korban, anak harus mendapatkan perlindungan dari semua pihak termasuk negara. Hal ini dikarenakan setiap anak yang berhadapan dengan hukum berhak mendapatkan perlindungan baik fisik, mental, spiritual maupun sosial sesuai dengan prinsipprinsip KHA.

Pemerintah telah berupaya memberi perhatiannya dalam wujud Undang Undang Nomor 23 Tahun 2002 tentang Perlindungan Anak, namun hal tersebut belum mampu menekan peningkatan kuantitas dan kualitas kasus yang melibatkan anak baik sebagai korban maupun pelaku tindak pidana. Terkait dengan perlindungan hukum terhadap anak, Indonesia telah meratifikasi konvensi hak anak melalui Keppres No. 36 Tahun 1990. Ratifikasi tersebut sebagai upaya negara untuk memberikan perlindungan terhadap anak. Dari berbagai isu yang ada dalam konvensi hak anak salah satunya yang sangat membutuhkan perhatian khusus adalah anak yang memerlukan perlindungan khusus diantaranya anak yang berhadapan dengan hukum. Dalam konvensi hak anak yang dimaksud dengan anak adalah setiap orang di bawah usia 18 tahun kecuali,berdasarkan hukum yang berlaku terhadap anak (Konvensi
Hak Anak, pasal 1) Prinsip utama Konvensi Hak Anak adalah "kepentingan terbaik anak". Semua tindakan yang ditetapkan berdasarkan konvensi mengambil prinsip tersebut sebagai titik tolaknya.(Konvensi Hak Anak, Pasal 32 sampai 36). Konvensi Hak Anak juga menetapkan alasan dan kondisi kondisi yang mendasari dapat dicabutnya kebebasan mereka secara sah serta hak anak yang didakwa telah melakukan pelanggaran hukum pidana atau anak sebagai pelaku tindak pidana (Konvensi Hak Anak, Pasal 337 dan 40). Ketentuan tersebut diatur lebih rinci di bawah judul penangkapan dan penahan.

Konvensi Hak-hak Anak (KHA) telah disetujui oleh Persatuan Bangsa-Bangsa (PBB) pada tahun 1989 dan telah diratifikasi oleh lebih dari 150 negara di dunia, termasuk Indonesia. Kendati Indonesia telah meratifikasi KHA melalui Keputusan Presiden Nomor 36 Tahun 1990, namunmasih banyak anak yang kehilangan haknya, seperti hak untuk memperoleh pendidikan. Akibatnya, banyak anak menjalani hidup mereka sendiri, tidak memiliki arah yang tepat. Oleh karena itu, banyak anak yang melakukan tindakan melawan hukum, seperti pencurian, perkelahian,atau menggunakan narkoba. Hal ini terjadi karena mereka sudah kehilangan hak yang seharusnya mereka miliki.

Terkait dengan perlindungan anak yang berhadapan dengan proses hukum, penerapan sistem peradilan pidana anak menjadi perhatian banyak pihak, terutama bagi para penegak hukum agar dapat mencari solusi demi mengurangi serta menyelesaikan permasalahan yang timbul. Polisi sebagai garda terdepan dalam penegakan hukum memiliki tanggung-jawab yang cukup besar sebagaimana yang telah diatur dalam Undangundang No. 2 Tahun 2002 tentang Kepolisian Negara Republik Indonesia dalam menangani anak pelaku tindak pidana, polisi senantiasa harus memperhatikan kondisi anak yang berbeda dari orang dewasa. Sifat dasar anak sebagai pribadi yang masih labil, masa depan anak sebagai aset bangsa, dan kedudukan anak di masyarakat yang masih membutuhkan perlindungan dapat dijadikan dasar untuk mencari suatu solusi alternatif bagaimana menghindarkan anak dari suatu sistem peradilan pidana formal, penempatan anak dalam penjara, dan stigmatisasi terhadap kedudukan anak sebagai narapidana. 


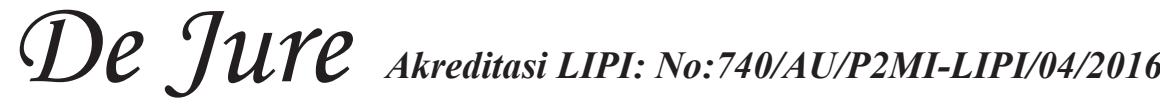

Berdasarkan uraian di atas, yang menjadi permasalahan dalam tulisan ini adalah bagaimana implementasi Konvensi Hak Anak (KHA) Terkait denga perlindungan anak yang berhadapan dengan proses hukum?.

\section{KERANGKA PEMIKIRAN}

\section{Definisi Anak}

Definisi anak menurut Konvensi Hak Anak Pasal 1 KHA yakni setiap manusia yang berusia dibawah 18 tahun kecuali Undang-Undang yang diterapkan untuk kasus mereka dalam hal ini "usia kedewasaan" ditetapkan pada usia yang lebih awal. Penetapan batas usia 18 tahun ini sama dengan penetapan batas usia bagi terminologi "anak" yang digunakan dalam ILO Worst Forms of Child Labour Convention. Soerjano Soekanto memberikan batasan usia remaja sebagai berikut:“....yang dapat mencakup anak-anak mudamudi adalah berkisar antara usia13 tahun sampai usia 18 tahun "(Soekanto, 1982: 21).

Sedangkan dalam Undang-Undang SPPA yakni pada Pasal 1 Angka 3 menyatakan anak yang Berkonflik dengan Hukum yang selanjutnya disebut Anak adalah anak yang telah berumur 12 (dua belas) tahun, tetapi belum berumur 18 (delapan belas) tahun yang diduga melakukan tindak pidana. Terkait usia minimum seorang anak dikategorikan anak nakal, (Adenwalla, 2006:17) berpendapat bahwa anak-anak baik laki-laki maupun perempuan yang berusia 18 tahunke bawah harus memperoleh perlindungan dari peraturan mengenai peradilan anak. Apapun alasannya, standar maksimal seorang anak dapatdipidana harus ditingkatkan dan sangat penting apabila standar tersebutmendekati batasan usia yang tertuang dalam KHA yaitu 18 tahun. Demikian juga dalam Undang-Undang Nomor 39 Tahun 1999 tentang Hak Asasi manusia menjabarkan pengertian tentang anak yaitu setiap manusia yang berusia di bawah 18 (delapan belas) tahun dan belum menikah termasuk anak yangmasih dalam kandungan apabila hal tersebut adalah demi kepentingannya.

\section{Konvensi Hak Anak}

A. Konvensi Anak dan Beijing Rulesterkait dengan Perlindungan Anak Pelaku Tindak Pidana

Ketentuan tentang hak anak telah menjadi bagian dari Deklarasi Universal Hak Asasi
Manusia. Namun, para aktivis perlindungan anak masih menuntut adanya ketentuan-ketentuan khusus terkait dengan jaminan perlindungan Hak Anak. Tuntutan tersebut kemudian direspon oleh Majelis Umum PBB pada tanggal 20 November 1959. Pada saat itu dikeluarkan Konvensi Hak Anak (KHA) yang menjadi dasar pijakan secara internasional mengenai pengakuan hak anak. KHA terdiri atas 54 pasal yang materinya mengatur mengenai hak anak dan mekanisme implementasi hak anak sebagai pihak yang meratifikasi KHA. Terkait dengan perlindungan Anak Pelaku Tindak Pidana, KHA juga mengatur beberapa hal terkait dengan keadaan dimana seorang anak berkonflik dengan hukum. Hal tersebut diatur dalam Pasal 37 KHA, bahwa jaminan yang harus diberikan oleh negara pihak dari KHA terhadap anak-anak seperti larangan pemberlakuan hukuman mati bagi anakanakdi bawah umur 18 tahun yang melakukan perbuatan pidana; penggunaan pidana penjara dan hal-hal lain terkait dengan perampasan kebebasan anak yang berkonflik hukum sebagai upaya terakhir dan untuk jangka waktu terpendek; apabila seorang anak dengan terpaksa harus dicabut kebebasannya karena berkonflik dengan hukum maka perlu dilakukan pemisahan dari orang dewasa dalam penempatannya.

Selain itu anak yang dirampas kebebasannya berhak mendapatkan bantuan hukum dan bantuan lain yang tepat dan juga berhak untuk menggugat keabsahan pihak yang berwenang mengeluarkan putusan perebutan kebebasannya. Selain jaminan yang disebutkan sebelumnya, KHA juga mengatur mengenai jaminan lain bagi anak yang berkonflik dengan hukum. Dalam Pasal 40 KHA diatur bahwa setiap anak yang berkonflik dengan hukum diperlakukan dengan cara bahwa dukungan terhadap anak tetap konsisten dengan nilai-nilai harkat dan martabat, bahwa penguatan terkait hak-hak asasi manusia bagi anak dan kebebasan-kebebasan mendasar lainya harus mempertimbangkan masalah usia anak serta kemampuan untuk mempromosikan reintegritas, anak juga mengupayakan peran konstruktif anak di masyarakat.

Sedangkan perlindungan anak pelaku tindak pidana dalam Beijing RulesPart two of United Nations Standard minimum Rules for the Administration of Juvenille Justice (Beijing Rules dinyatakan bahwa setiap negara pihak hendaknya menjadikan peradilan anak sebagai bagian 
integral dari proses pembangunan nasional sebuah negara. Selain itu, proses peradilan anak harus mengutamakan kesejahteraan anak dan keluarga. Sehingga pada saat yang bersamaan hal tersebut dapat memberikan andil bagi perlindungan kaum muda dan pemeliharaan keterlibatan yang damai dalam masyarakat. Beijing Rules tidak memberikan batasan yang tegas mengenai usia anak harus menjalani pertanggungjawaban hukum. Pada paragraf 4.1 menyatakan bahwa konsep usia pertanggungjawaban tindak pidana tidak dapat ditetapkan terlalu rendah, mengingat pertimbangan kedewasaan emosional, mental, dan intelektual. Untuk dapat menentukan batas usia pertanggungjawaban tindak pidana yang diterima secara internasional dengan merujuk pada praktekpraktek yang dijalankan oleh negara-negara lain(Yayasan Pemantau Hak Anak, tanpa tahun :19). Beijing Rules hanya mencantumkan pernyataan bahwa akan dilakukan upaya-upaya untuk menyetujui suatu batas usia paling rendah yang cukup layak untuk usia pertanggungjawaban pidana anak secara internasional. Dengan kata lain, pertimbangan utama dalam penentuan usia anak untuk bertanggungjawab secara pidana harus mempertimbangkan proporsionalitas antara perlakuan terhadap anak dengan perbuatan pidana yang dilakukannya.Beijing Rules juga menegaskan bahwa perlu diupayakan adanya diversi dalam proses peradilan anak. Diversi hendaknya diberikan untuk menangani pelanggar hukum berusia muda tanpa menggunakan pengadilan formal oleh pihak berwenang. Selain itu, berbagai bentuk pembinaan di luar lembaga (noninstitusional) harus menjadi pilihan utama dibandingkan dengan pemenjaraan. Hal tersebut mempertimbangkan dampak yang akan ditimbulkan ketika seorang anak harus menjalani hukuman pemenjaraan. Karena Beijing Rules merupakan turunan lanjutan dari konvensi hak anak maka Beijing Rules juga dapat digunakan bagi pembangunan hukum nasional khususnya dalam bagaimana memperlakukan anak yang berhadapan dengan hukum.

\section{B. Konvensi Hak Anak dan Beijing Rule terkaitPerlindungan Anak Pelaku Tindak Pidana Dalam Proses Penyidikan}

Penjabaran terhadap pengaturan perlindungan anak dalam intrumen hukum internasional terlihat dalam Konvensi Hak-Hak Anak 1989 (Convention on the Rights of the Child) dimana konvensi ini merupakan akar dari perlindungan anak secara umum dalam hukum internasional, namun Pasal 40 dalam konvensi ini yang khusus mengatur tentang Perlindungan Anak Pelaku Tindak Pidana $\mathrm{d}$ alam Proses Peradilan Pidana khususnya dalam proses penyidikan, yang berisi: (Hadisuprapto, 1997, hal.94-96)

1. Negara-negara Anggota mengakui hak setiap anak yang dinyatakaan sebagai terdakwa atau diketahui telah melanggar hukum pidana, untuk diperlakukan sedemikian rupa, sesuai dengan kemajuan pengertian anak tentang harkat dan martabatnya, sambil mengusahakan agar anak mempunyai rasa hormat pada hak-hak asasi dan kebebasan pihak lain, dengan tetap mempertimbangkan usia dan keinginan anak dalam rangka mengintegrasikannya kembali sesuai dengan peran konstruktifnya di masyarakat. Selain itu, negara-negara anggota harus secara khusus menjamin bahwa:

a. Tidak boleh anak didakwa, dituntut, atau dinyatakan telah melanggar hukum pidana dengan alasan perbuatan atau kelalaiannya itu tidak dilarang oleh hukum nasional atau internasional pada saat perbuatan pelanggaran itu dilakukannya.

b. Setiap anak yang didakwa atau dituntut sebagai pelaku pelanggaran hukum pidana harus paling tidak dijamin hakhaknya berikut ini:

(i) anak dianggap tak bersalah sampai ada pembuktian kesalahannya secara hukum;

(ii) anak berhak diberitahu dengan jelas dan langsung tuduhan yang ditujukan terhadapnya, apabila perlu, dilakukan melalui orang tuanya atau kuasa hukumnya dan kepada mereka diberikan bantuan hukum dalam rangka persiapan pembelaannya;

(iii) demi kepastian hukum dan mencegah terjadinya penundaan penanganan, oleh lembaga yang berkompeten, bebas dan tak memihak atau lembaga yudisial dalam kerangka pemeriksaan yang fair sesuai hukum yang berlaku, anak harus didampingi penasihat hukumnya, kecuali adanya 


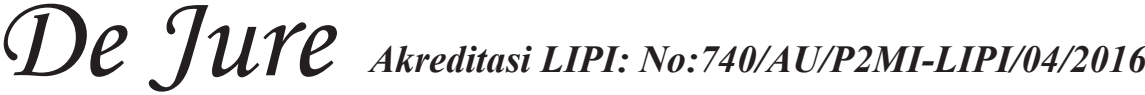

alasan-alasan demi kepentingan terbaik anak, namun dengan tetap memperhatikan usia dan situasi anak, orang tua atau kuasa hukumnya;

(iv) agar tidak ada paksaan dalam memberikan kesaksian atau pengakuan bersalah; pengujian terhadapkesaksianyangmerugikan anak dan untuk memperoleh kepastian bahwa peran serta saksi dan pengujian kesaksiannya betul-betul atas kehendak anak, pengujian itu harus dilandaskan atas dasar persamaan hak;

(v) bila dipertimbangkan adanya pelanggaran hukum pidana, keputusan dan setiap tindakan yang dijatuhkan harus di bawah pengawasan pihak yang lebih berkompeten, bebas dan tak memihak atau badan yudisial sesuai ketentuan hukum yang berlaku;

(vi) anak yang tidak memahami atau tidak bisa berbicara bahasa yang digunakan, harus dibantu seorang penerjemah yang bebas.

(vii) anak berhak menikmati privacynya di semua tingkatan pemeriksaan.

2. Negara anggota dalam mendukung Konvensi ini harus menetapkan Hukum, prosedur, pihak-pihak yang diberi wewenang, lembaga khusus untuk menanngani anak yang didakwa, dituntut, atau dinyatakan sebagai pelaku pelanggaran hukum pidana, secara khusus:

a. penetapan batas usia minimal terendah bagi seorang anak yang dinyatakan belum layak dinyatakan sebagai pelaku pelanggaran hukum pidana;

b. apabila diperlukan dan dikehendaki, tindakan terhadap anak yang dilakukan tanpa melibatkan proses peradilan, persyaratan hak asasi manusia dan kuasa hukum harus dipenuhi.

Selain itu, prinsip perlindungan hukum dalam intstrumen hukum internasional khusus terhadap anak pelaku tindak pidana diatur dalam United Nations Standard Minimum Rules for the
Administration of Juvenile Justice (Beijing Rules). Beijing Rules disetujui pada tanggal 6 September 1985 dan menjadi Resolusi PBB pada tanggal 29 November 1985 dalam Resolusi 40/33. Beijing Rules membahas tentang perlindungan terhadap anak dalam pelaksanaan sistem peradilan pidana, yakni diantaranya sebagai berikut:

\section{a. General Principles (Asas Umum)}

Bagian ini secara umum berisi tentang perlunya Kebijakan Sosial yang Komprehensif yang bertujuan untuk mendukung tercapainya sebesar mungkin kesejahteraan anak, yang pada gilirannya akan mengurangi campur tangan sistem peradilan anak. Artinya kebijakan sosial yang diatur dalam bagian ini benar-benar bertujuan untuk memberikan kesejahteraan terhadap anak, hal tersebut dapat tercapai apabila dilakukan dengan tidak mendekatkan atau melibatkan anak dengan sistem peradilan pidana anak terhadap anak pelaku tindak pidana.

\section{b. Penyelidikan dan Penuntutan}

Penanganan anak di tingkat penyelidikan harus dihindari dari sikap yang mengarah pada penekanan terhadap anak seperti pertanyaan yang bersifat gertakan bernada keras maupun tindakan kekerasan (kontak fisik), agar tidak menimbulkan ketakutan dari dalam diri anak. Diversi (pengalihan), suatu mekanisme yang memungkinkananakdialihkandariprosesperadilan menuju proses pelayanan sosial diprioritaskan, karena keterlibatan anak dalam proses peradilan sebetulnya telah mengalami proses stigmatisasi.

\section{c. Batasan Usia Anak}

Usia anak yang berkonflik dengan hukum ialah anak yang berusia 12 (dua belas) tahun sampai 18 (delapan belas) tahun. Usia yang dapat dilakukan penahanan ialah usia 14 (empat belas) tahun atau lebih atau dengan memperhatikan tindak pidana yang dilakukan. Anak yang usianya belum mencapai 12 (dua belas tahun) hanya dapat dilakukan pembimbingan dan pembinaan terhadap anak. Ketentuan batas usia Anak ini telah sesuai dengan Beijing Rules yang menentukan bahwa dalam menentukan batas usia anak harus memperhatikankeadaan Anak dan tidak ditentukan terlalu rendah. Konvensi Hak-Hak Anak juga menyebutkan bahwa setiap negara anggota herus menentukan batas usia minimum yang belum dapat diterapkan sistem peradilan pidana, dimana dalam undang-undang ini sudah menentukan hal tersebut. 


\section{PERLINDUNGAN ANAK YANG BER- HADAPAN DENGAN PROSES HUKUM}

Terkait dengan tindak pidana oleh anak atau anak pelaku tindak pidana, Olivia Sembiring, dalam tulisanya yang berjudul Perlindungan Hukum Terhadap Anak yang Berkonflik dengan Hukum, mendefenisikan Juvenile Delinquency sebagai perilaku jahat (dursila) atau kejahatan atau kenakalan anak-anak muda yangmerupakan gejala sakit (patalogis) secara sosial kepada anak-anak dan remaja yang disebabkan oleh bentuk tingkah laku yang menyimpang.(Adenwalla, 2006, 17)

Sistem Peradilan Pidana Anak (Juvenile Justice System) adalah segalaunsursistem peradilan pidana yang terkait di dalam penanganan kasuskasus kenakalan anak. Pertama, polisi sebagai institusi formal ketika anak nakal pertama kali bersentuhan dengan sistem peradilan, yang juga akan menentukan apakah anak akan dibebaskan atau diproses lebih lanjut. Kedua, jaksa dan lembaga pembebasan bersyarat yang juga akan menentukan apakah anak aka dibebaskan atau diproses ke pengadilan anak. Ketiga, Pengadilan Anak, tahapan ketika anak akan ditempatkan dalam pilihan-pilihan, mulai dari dibebaskan sampai dimasukkan dalam institusi penghukuman. Yang terakhir, institusi penghukuman (Allen, Kata Pengantar, dalam Purnianti, Mamik Sri Supatmi, dan Ni Made Martini Tinduk, Analisa)

Terkait dengan proses penyidikan, dalam ketentuan KUHAP tentang penyidikan didefenisikan bahwa penyidikan merupakan serangakaian tindakan penyidik dalam hal dan menurut cara yang diatur dalam Undang-Undang ini (KUHAP) untuk mencari serta mengumpulkan bukti yang dengan bukti tersebuut membuat terang tentang tindak pidana yang terjadi dan guna menemukan tersangkanya (Pasal 1 butir 2 KUHAP) Tindakan itu dapat meliputi pemanggilan dan pemeriksaan saksi-saksi, penyitaan alat-alat bukti, pengeledahan, pemanggilan dan pemeriksaan tersangka, melakukan penangkapan, melakukan penahanan, dan lain sebagainya. Sementara penyidik sesuai Pasal 1 angka 1 KUHAP, adalah Pejabat Polisi Negara RI atau Pejabat Pegawai Negeri Sipil tertentu yang diberi wewenang khusus oleh Undang-Undang untuk melakukan penyidikan. Penyidikan yang dilakukan oleh pejabat kepolisian negara RI bertujuan untuk mengumpulkan bukti guna menemukan apakah suatu peristiwa yang terjadi merupakan peristiwa pidana, dengan penyidikan juga ditujukan untuk menemukan pelakunya. Setelah adanya penyidikan tahapan selanjutnya dilakukan penyelidikan. Penyelidikan kasus pidana anak dilakukan oleh kepolisian sesuai dengan KUHAP dan UndangUndang SPPA. Penyelidikan kasus anak pelaku tindak pidana dilakukan oleh kepolisian sesuai dengan KUHAP dan Undang-Undang SPPA. Polisi dalam melakukan penyelidikan terhadap anak pelaku tindak pidana harus memperhatikan berbagai ketentuan mengenai upaya penangan anak mulai dari penangkapan sampai proses penempatan (Marlina, 2009:85)

Ada 2 (dua) kategori perilaku anak yang membuat ia berhadapan dengan hukum atau sebagai pelaku tindak pidana, yaitu (Marlina, 2009:85):

a. Status Offender adalah perilaku kenakalan anak yang apabila dilakukan oleh orang dewasa tidak dianggap sebagai kejahatan, seperti tidak menurut, membolos sekolah atau kabur dari rumah;

b. Juvenile Delinquency adalah perilaku kenakalan anak yang apabila dilakukan oleh orang dewasa dianggap kejahatan atau pelanggaran hukum

Pelaksanaan Sitem Peradilan Pidana Anak ditegakkannya demi mencapai kesejahteraan anak dengan berdasar prinsip kepentingan terbaik bagi anak. Dengan kata lain, Sitem Peradilan Pidana Anak berdasarkan pada perlindungan anak dan pemenuhan hak-hak anak (protection child and fullfilment child rights based approach).

Perlindungan khusus bagi anak pelaku tindak pidana dilaksanakan melalui tindakan-tindakan sebagai berikut(Pasal 64 ayat (2) Undang-undang No. 23 Tahun 2002 tentang Perlindungan Anak.)

a. Perlakuan anak secara manusiawi sesuai dengan martabat dan hak-hak anak;

b. Penyediaan petugas pendamping khusus anak sejak dini;

c. Penyediaan sarana dan prasarana khusus;

d. Penjatuhan sanksi yang tepat untuk kepentingan yang terbaik dengan anak.;

e. Pemantauan dan pencatatan terus menerus terhadap perkembangan anak yang berhadapan dengan hukum (anak pelaku tindak pidana); 


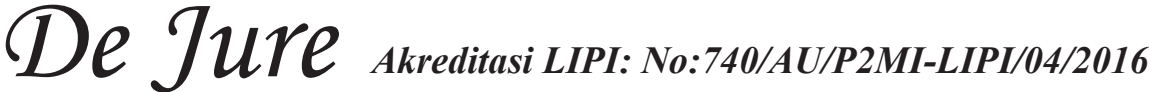

f. Pemberian jaminan untuk mempertahankan hubungan dengan orangtua atau keluarga; dan;

g. Perlindungan dari pemberitaan identitas melalui media massa danuntuk menghindari labelisasi.

\section{Perlindungan Anak Pelaku Tindak Pidana dalam Proses Penyidikan}

\section{Penyidik Anak}

Perkara pidanayang dilakukan oleh anak-anak pada umumnya ketentuan yang dilanggar adalah peraturan pidana yang terdapat dalam KUHP, maka penyidikannya dilakukan oleh penyidik umum dalam hal ini penyidik Polri. Sejalan akan diberlakukannya dengan diberlakukannya Undang-Undang Sistem Peradilan Pidana Anak, telah dipertegas bahwa penyidikan terhadap perkara anak nakal dilakukan oleh penyidik Polri dengan dasar hukum Pasal 26 ayat (1) Nomor 11 Tahun 2012 tentang Sistem Peradilan Pidana Anak dan yang pada intinya menyebutkan bahwa "penyidikan terhadap perkara anak dilakukan oleh penyidik yang ditetapkan berdasarkan Surat Keputusan Kepala Kepolisian RI atau pejabat lain yangditunjukolehKapolri”. Meskipunpenyidiknya penyidik Polri, akan tetapi tidak semua penyidik Polri dapat melakukan penyidikan terhadap perkara anak nakal. Undang-Undang Sistem Peradilan Pidana Anak dikenal adanya penyidik anak, yang berwenang melakukan penyidikan. Penyidik anak diangkat oleh Kapolri dengan Surat Keputusan Khusus untuk kepentingan tersebut. Undang - Undang Sistem Peradilan Pidana Anak melalui Pasal 26 Ayat (3) menetapkan syarat syarat yang harus dipenuhi oleh seorang Penyidik adalah :

1. Telah berpengalaman sebagai penyidik;

2, Mempunyai minat, perhatian, dedikasi dan memahami masalah anak.

3. Telah mengikuti pelatihan teknis tentang peradilan Anak

Perlindungan hukum terhadap anak dalam proses peradilan dilakukan dimulai semenjak tingkat penyelidikan, penyidikan, penuntutan, pemeriksaan di sidang pengadilan sampai pada pelaksanaan putusan pengadilan tersebut. Selama proses peradilan tersebut, maka hak-hak anak wajib dilindungi oleh hukum yang berlaku dan oleh sebab itu harus dilakukan secara konsekuen oleh pihak-pihak terkait dengan penyelesaian masalah anak nakal tersebut.

\section{Proses Peyidikan Anak}

Kekuasaan Penyidikan adalah tahap yang paling menentukan dalam operasionalisasi Sistem Peradilan Pidana Terpadu tersebut dalam rangka tercapainya tujuan dari Penegakan Hukum Pidana, karena pada tahap penyidikanlah dapat diketahui adanya tersangka suatu peristiwa kejahatan atau tindak pidana serta menentukan tersangka pelaku kejahatan atau tindak pidana tersebut sebelum pelaku kejahatan tersebut pada akhirnya dituntut dandiadili di pengadilan serta diberi sanksi pidana yang sesuai dengan perbuatannya. Tanpa melalui proses atau tahapan penyidikan maka secara otomatis, tahapan-tahapan selanjutnya dalam proses peradilan pidana yaitu tahapan penuntutan, pemeriksaan di muka pengadilan dan tahap pelaksanaan putusan pidana tidak dapat dilaksanakan.

Penyidikan itu sendiri, berarti serangkaian tindakan penyidik, dalam hal dan menurut cara yang diatur dalam Undang-Undang ini untuk mencari dan mengumpulkan bukti yang dengan bukti itu membuat terang tentang tindak pidana yang terjadi dan guna menemukan tersangkanya[13], sedangkan "bukti", dalam ketentuan tersebut di atas adalah meliputi alat bukti yang sah dan benda sitaan/barang bukti. Di Indonesia, masalah kewenangan dan ketentuan mengenai "Penyidikan" diatur di dalam UU No. 8 tahun 1981 tentang Kitab Undang-Undang Hukum Acara Pidana yang menjadi dasar hukum pidana formil di Indonesia. Ketentuan mengenai aparat yang berwenang untuk melakukan penyidikan, selain diatur di dalam KUHAP, juga diatur di dalam Peraturan Perundang-undangan lain di luar KUHAP.

Tindakan yang dapat dilakukan penyidik adalah penangkapan, penahanan, mengadakan pemeriksaan ditempat kejadian, melakukan penggeledahan, pemeriksaan tersangka dan interogasi, membuat Berita Acara Pemeriksaan (BAP), penyitaan, penyimpanan perkara, melimpahan perkara. Penyidikan yang diterapkan dalam Undang-Undang Nomor 11 Tahun 2012 tentang Sistem Peradilan Pidana Anak harus dipandang sebagaimana layaknya status dan fungsi seorang penyidik menurut KUHAP. Penyidikan terhadap anak yang berhadapan dengan hukum dilakukan oleh penyidik anak yang ditetapkan 
berdasarkan Surat Keputusan Kepala Kepolisian RI atau pejabat yang ditunjuknya. Penyidikan terhadap anak tersebut haruslah dalam suasana kekeluargaan sebagaimana diatur dalam Pasal 18 UU RI No. 11 Tahun 2012 Tentang Sistem Peradilan Pidana Anak menyebutkan bahwa Dalam menangani perkara Anak, Anak Korban, dan/atau Anak Saksi,Pembimbing Kemasyarakatan, Pekerja Sosial Profesional dan Tenaga Kesejahteraan Sosial, Penyidik, Penuntut Umum, Hakim, dan Advokat atau pemberi bantuan hukum lainnya wajib memperhatikan kepentingan terbaik bagi Anak dan mengusahakan suasana kekeluargaan tetap terpelihara.

Pasal 27 ayat 1 UU No. 11 tahun 2012, menentukan bahwa dalam melakukan penyidikan anak nakal, penyidik dibantu pembimbing kemasyarakatan. Pasal 65 ayat 1 huruf b UU No. 11 Tahun 2012, menentukan bahwa pembimbing kemasyarakatan bertugas membantumemperlancar penyidikan dengan membuat laporan penelitian kemasyarakatan. Penyidikan dalam perkara Anak melibatkan peran serta dari Pembimbing Kemasyarakatan, yakni dengan diwajibkannya Penyidik untuk meminta pertimbangan saran dari Pembimbing Kemasyarakatan setelah tindak pidana dilaporkan atau diadukan, Berdasarkan Pasal 1 angka 13 UU SPPA, Pembimbing Kemasyarakatan adalah pejabat fungsional penegak hukum yang melaksanakan penelitian kemasyarakatan, pembimbingan, pengawasan, dan pendampingan terhadap anak di dalam dan di luar proses peradilan anak. Secara sederhana dapat dikatakan bahwa PK Bapas merupakan salah satu dari petugas kemasyarakatan yang mempunyai peran penting bersama-sama dengan penegak hukum lainnya untuk mengupayakan perlindungan bagi anak dalam proses peradilan anak agar mendapatkan perlindungan sehingga hak-hak mereka dapat terjamin di mata hukum. Proses penyidikan anak nakal, wajib dirahasiakan ( Pasal 19 ayat 1 UU No. 11 Tahun 2012).

Penyidik juga wajib meminta laporan Hasil Penelitiaan Kemasyarakatan terhadap Anak Korban dan Anak Saksi dari Pekerja Sosial Profesional atau Tenaga Kesejahteraan Sosiall sejak tindak pidana diajukan. Masing-masing hasil laporan tersebut wajib diserahkan oleh Balai Pemasyarakatan kepada Penyidik dalam waktu selambat-lambatnya 3 x 24 jam. Penangkapan terhadap Anak dilakukan guna penyidikan paling lama 24 jam. Anak yang ditangkap wajib ditempatkan di ruang khusus unit pelayanan Anak, dan Penyidik harus berkoo dengan Penuntut Umum guna memenuhi kelengkapan berkas baik secara materiil maupun formil dalam waktu $1 \mathrm{x}$ 24 jam.

Tindakan penyidik berupa penangkapan, penahanan, dan tindakan lain yang dilakukan mulai dari tahap penyelidikan hingga tahap penyidikan, wajib dilakukan secara rahasia. Perkara anak dapat diajukan ke sidang pengadilan sesuai Pasal 20 UU No. 11 Tahun 2012 adalah perkara anak yang berumur 12 tahun dan belum genap berumur 18 tahun dan diajukan ke sidang pengadilan setelah Anak yang bersangkutan melampaui batas umur 18 (delapan belas) tahun, tetapi belum mencapai umur 21 (dua puluh satu) tahun, Anak tetap diajukan ke sidang Anak. Namun pasal 24 UU No.11 tahun 2012, masih memungkinkan dilakukan penyidikan anak yang berumur dibawah 12 tahun, namun berkas perkaranya tidak akan dilimpahkan ke kejaksaan untuk dilakukan penuntutan di persidangan. Tujuan dilakukan penyidikan terhadap anak yang belum berumur 12 tahun yang diduga melakukan tindak pidana adalah untuk mengetahui bahwa anak yang bersangkutan melakukan tindak pidana seorang diri atau ada orang lain yang terlibat atau anak yang bersangkutan melakukan tindak pidana bersama-sama dengan orang lain atau Tentara Nasional Indonesia (TNI), dalam hal ini yang berumur 12 tahun keatas dan atau dengan orang dewasa atau TNI.

Berikut prosedur yang dilakukan untuk anak pelaku tindak pidana pada tahap penyidikan :

\section{Penangkapan}

Penangkapan adalah suatu tindakan Penyidik berupa pengekangan sementara waktu kebebasan tersangka atau terdakwa apabila terdapat cukup buktiguna kepentingan penyidikan atau penuntutan dan atau peradilan dalam hal serta menurut cara yang diatur dalam Undang-Undang. Mengenai tindakan penangkapan tidak diatur secara rinci dalam Mengenai tindakan penangkapan tidak diatur secara rinci dalam UndangUndang No. 11 Tahun 2012 tentang Sistem Peradilan Pidana Anak (SPPA), sehingga berlaku ketentuanketentuan dalam UndangUndang No.8 Tahun 1981 tentang Kitab Undang-Undang Hukum Acara Pidana(KUHAP). Undang-Undang ini mengatur wewenang polisi dalam melakukan penyidikan 


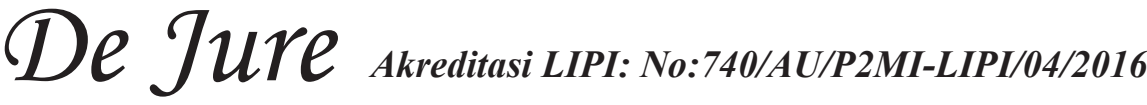

dan penyelidikan yang selanjutnya diatur dalam petunjuk pelaksanaan (juklak) dan petunjuk teknis (juknis) kepolisian. Aturan tersebut menjadi pedoman bagi setiap anggota kepolisian RI dalam menjalankan tugas dan fungsinya.

Upaya memberikan perlindungan terhadap anak pelaku tindak pidana, disamping juklak dan juknis yang dimiliki, ada beberapa cara penanganan terhadap anak, yakni tindakan penangkapan diatur dalam Pasal 16 sampai Pasal 19 KUHAP. Berdasarkan Pasal 16 KUHAP dapat diketahui bahwa tujuan penangkapan tersangka ialah untuk kepentingan penyelidikan dan penyidikan. Perintah penangkapan dilakukan terhadap seseorang yang diduga keras melakukan tindak pidana berdasarkan bukti yang cukup. Terkait dengan tindakan penangkapan terhterhadap anak yang berhadapan atau anak pelaku tindak pidana, polisi memperhatikan hak-hak anak dengan melakukan tindakan perlindungan terhadap anak, seperti antara lain perlakukan anak dengan asas praduga tak bersalah, perlakukan anak dengan arif, santun dan bijaksana, dan tidak seperti terhadap pelaku tindak pidana dewasa.

\section{Pemeriksaan Anak}

Penyidik wajib memeriksa tersangka dalam suasana kekeluargaan (Pasal 18 UU No. 11 Tahun 2012). Kentuan ini menghendaki bahwa pemeriksaan dilakukan dengan pendekatan secara efektif dan simpatik. Efektif dapat diartikan, bahwa pemeriksaannya tidak memakan waktu lama, dengan menggunakan bahasa yang mudah dimengerti, dan dapat mengajak tersangka memberikan keterangan yang sejelas-jelasnya. Simpatik maksudnya pada waktu pemeriksaan, penyidik bersikap sopan dan ramah serta tidak menakut-nakuti tersangka. Tujuannya adalah agar pemeriksan berjalan dengan lancar, karena seorang anak yang merasa takut sewaktu menghadapi penyidik, akan mengalami kesulitan untuk mengungkapkanketeranganyang benardan sejelasjelasnya. Pada waktu pemeriksaan tersangka, penyidik tidak memakai pakaian seragam. Proses pemeriksaan terhadap tersangka anak merupakan bagian dari kegiatan penyidikan yang bertujuan untuk mendapatkan keterangan, kejelasan dan keidentikan tersangka dan barang buktinya. Juga dierlukan kemampuan khusus yang harus dimiliki oleh pemeriksa sehingga dalam pelaksanaannya perlakuan-perlakuan yang diberikan kepada anak harus dibedakan dengan tersangka dewasa. Dalam proses pemeriksaan wajib dilaksanakan dengan menjunjung tingggi hukum yang berlaku serta senantiasa memperhatikan hak asasi manusia sebagaimana diatur dalam KUHAP.

Dalam prakteknya, dari hasil wawancara yang dilakukan dengan pejabat Kepolisian Sumatera Selatan, menyatakan, pola pemeriksaan dan penanganan perkara di Kepolisian masih belum sepenuhnya sejalan dengan konsep UU SPPA. Hal tersebut dibuktikan dengan formasi penyidik anak yang banyak diduduki oleh polisi wanita dan dikatakan dalam wawancara bahwa kepolisian masih memiliki keterbatasan jumlah personil Polisi Wanita (Hasil Wawancara Penelitian Tim Hukum "Kesiapan Pemerintah dan Aparat Penegak Hukum dalam Melaksanakan UU No. 11 Tahun 2012 tentang Sistem Peradilan Pidana Anak" dengan Kompol Suratmi, Kepolisian Resort Kota Besar Surabaya, 12 Agustus 2014) Selain itu, walaupun telah memiliki unit PPA, di dalam unit tersebut perkara yang ditangani lebih banyak perkara cabul. Ketika anak melakukan tindak pidana lain, maka disposisi perkara tersebut tergantung kebijakan pimpinan, tidak semua perkara anak diselesaikan oleh Unit PPA. Perkara anak selain perkara cabul kemungkinan besar akan ditangani oleh unit kriminal umum dan kriminal khusus untuk perkara narkotika, karena jenis perkaranya masih merupakan kewenangan kriminal umum dan kriminal khusus.

Hal tersebut terjadi di dua wilayah yang menjadi objek penelitian yaitu Sumatera Selatandan Jawa Timur. Namun, permasalahan tersebut kemudian diatasi dengan adanya koordinasi antara penyidik perkara anak yang tidak di Unit PPA dengan penyidik yang ada di Unit PPA selama perkara anak tersebut diperiksa (Hasil Wawancara Penelitian Tim Hukum "Kesiapan Pemerintah dan Aparat Penegak Hukum dalam Melaksanakan UU No. 11 Tahun 2012 tentang Sistem Peradilan Pidana Anak" dengan Kompol Suratmi, Kepolisian Resort Kota Besar Surabaya, 12 Agustus 2014) Penyidik dari unit lain akan mendapatkan arahan khusus dari penyidik anak yang ada di Unit PPA tentang bagaimana memperlakukan anak dalam penyidikan dan bantuan dalam upaya Diversi(Hasil Wawancara Penelitian Tim Hukum "Kesiapan Pemerintah dan Aparat Penegak Hukum dalam Melaksanakan UU No. 11 Tahun 2012 tentang Sistem Peradilan Pidana 
Anak" dengan Kompol Retno Kanit V Subdit IV Renakta DitreskrimumKepolisian Daerah Sumatera Selatan, 28 Maret 2014).

\section{Penghentian Penyidikan}

Penyidikan merupakan kompetensi Penyidik, termasuk menghentikannya (Pasal 109 ayat [2] KUHAP). Alasan pemberian wewenang penghentian penyidikan ada 2 (dua), yaitu :

a. Untuk menegakkan prinsip penegakan hukumyangcepat, tepat, danbiayaringan, sekaligus untuk tegaknya kepastian hukum dalam kehidupan masyarakat. Jika Penyidik berkesimpulan bahwa hasil penyelidikan dan penyidikan tidak cukup bukti atau alasan untuk menuntut tersangka ke persidangan, Penyidik secara resmi menyatakan penghentian pemeriksaan penyidikan, agar dengan demikian segera tercipta kepastian hukum.

b. Supaya penyidikan terhindar dari kemungkinan tuntutan ganti kerugian, jika perkaranya diteruskan ternyata tidak cukup bukti atau alasan untuk menuntut ataupun menghukum, dengan sendirinya memberi hak kepada tersangka/terdakwa untuk menuntut ganti kerugian berdasarkan Pasal 95 KUHAP.

Dalam menghentikan penyidikan, ada beberapa alasan sebagaimana ditentukan dalam Pasal 109 ayat (2) KUHAP, yaitu:

a. Tidak diperoleh bukti yang cukup; Penyidik sering tidak mengabaikan kekuatan bukti-bukti perkara yang diajukan ke Penuntut Umum. Hal ini menyulitkan penegakan keadilan.

b. Peristiwa yang disangkakan bukan merupakan tindak pidana; jika kasus hukum yang disangkakan bukan termasuk perkara pidana, melainkan perkara perdata, maka pemeriksaan perkara itu dihentikan.

c. Penghentian penyidikan demi hukum; pada pokoknya sesuai dengan alasanalasan hapusnya hak menuntut dan hilangnya hak menjalankan pidana. Menegakkan asas nebis in idem (seseorang tidak boleh dituntut untuk kedua kalinya terhadap suatu perkara yang sudah pernah diadili dan telah diputus perkaranya oleh Hakim atau pengadilan yang berwenang, dan putusan itu telah mempunyai kekuatan hukum yang tetap). Apabila tersangka meninggal dunia, maka perkaranya harus dihentikan dan lain-lain alasan penghentian penyidikan.

d. Delik yang terjadi merupakan delik aduan, yang dapat dilakukan pencabutannya

e. Penghentian penyidikan juga dilakukan apabila ada perdamaian antara pihak anak pelaku tindak pidana dengan korban.

f. Penghentian penyidikan juga dilakukan apabila ada perdamaian antara pihak anak nakal dengan korban. Hal ini merupakan penyimpangan, karena perdamaian tidak dikenal dalam perkara pidana. Seyogyanya penghentian penyidikan dilakukan atas pertimbangan kepentingan anak, terlepas dari ada perdamaian atau tidak. Apabila penuntut umum berpendapat bahwa hasil penyidikan tersebut masih kurang lengkap, maka penuntut umum segera mengembalikan berkas perkara kepada penyidik, disertai petunjuk untuk dilengkapi. Setelah penyidik menerima berkas perkara tersebut, penyidik wajib melakukan penyidikan tambahan dan dalam tempo 14 hari setelah pengembalian berkas perkara dari penuntut umum, penyidik sudah menyiapkan pemeriksaan penyidikan tambahan ( disempurnakan) dan diserahkan lagi kepada penuntut umum ( Pasal 110 ayat 1 KUHAP ).

\section{Penahanan}

Penahanan ialah penempatan tersangka atau terdakwa di tempat tertentu oleh Penyidik, atau Penuntut Umum atau Hakim dengan penetapannya, dalam hal serta menurut cara yang diatur dalam Undang-Undang(Pasal 1 butir 21 KUHAP). Dalam Undang-Undang SPPA penahanan terhadap Anak hanya dapat dilakukan dengan syarat bahwa anak telah berumur 14 (empat belas) tahun atau lebih; dan diduga melakukan tindak pidana dengan ancaman pidana penjara 7 (tujuh) tahun atau lebih. Selain itu, KUHAP, menetukan bahwa tersangka 


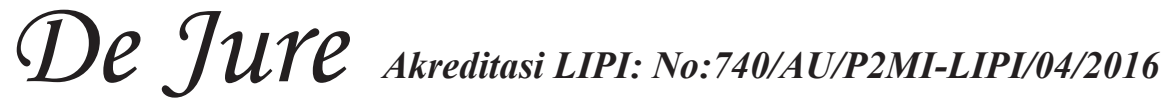

atau terdakwa dapat ditahan. Karena ada istilah "dapat" ditahan, berarti penahanan anak tidak selalu dilakukan, sehingga dalam hal ini Penyidik diharapkan betul-betul mempertimbangkan apabila melakukan penahanan anak. Menurut Pasal 21 ayat (1) KUHAP, alasan penahanan adalah karena ada kekhawatiran melarikan diri, agar tidak merusak atau menghilangkan barang bukti, agar tidak mengulangi tindak pidana. Menurut hukum acara pidana, menghilangkan kemerdekaan seseorang tidak merupakan keharusan, tetapi untuk mencari kebenaran bahwa seseorang melanggar hukum, kemerdekaan seseorang itu dibatasi dengan melakukan penangkapan dan penahanan.

Adanya perlakuan khusus terhadap anakanak yang melanggar hukum, sebagai konsekwensi dimilikinya karakteristik khusus pada diri anak, pada dasarnya merupakan salah satu wujud dari perlindungan anak sebagaimana disebutkan dalam Pasal 16 ayat (3) Undangundang No. 23 Tahun 2002 tentang Perlindungan Anak, yang menyatakan: "Penangkapan, penahanan, atau tindak pidana penjara anak hanya dilakukan apabila sesuai dengan hukum yang berlaku dan hanya dapat dilakukan sebagai upaya terakhir." Dalam menghadapi dan menanggulangi berbagai perilaku anak yang melakukan perbuatan menyimpang (bermasalah dengan hukum) hendaknya dipertimbangkan kedudukan anak dengan segala ciri dan sifatnya yang khas, sehingga dalam menjatuhkan tindakan penahanan terhadap anak diupayakan agar anak tidak dipisahkan dari orang tuanya. Namun, apabila pemisahan anak dari orang tuanya tidak dapat dihindarkan, maka pemisahan harus didasarkan atas pertimbangan demi pertumbuhan dan perkembangan anak secara sehat dan wajar.

\section{KESIMPULAN}

Perlindungan hukum terhadap Anak pelaku tindak pidana dalam proses penyidikan mengacu kepada Konvensi Hak-Hak Anak (Convention on The Rights of The Child) dan Beijing Rule. Penjabaran perlindunganhukumanak pelakutindak pidana dalam konvensi tersebut telah mencakup sebagian besar prinsip perlindungan anak pelaku tindak pidana baik dalam instrumen hukum nasional maupun instrumen hukum internasional. Dalam hukum nasional sebagai penjabaran dari Konvensi Hak Anak tersebut dilakukan harmonisasi hukum melalui Undang-Undang No.
23 tahun 2002 tentang Perlindungan Anak dan Undang-Undang SPPA. Harmonisasi tersebut dapat dilihat pada isi setiap perundang-undangan yang ada terkait perlindungan anak terutama anak pelaku tindak pidana. seperti Penanganan anak di tingkat penyelidikan harus dihindari dari sikap yang mengarah pada penekanan terhadap anak, penanganan anak diupayakan melakukan diversi, dll.

Perlindungan dalam proses penyidikan kepada anak pelaku tindak pidana yang dilakukan oleh anak adalah sebagai bentuk perhatian dan perlakuan khusus untuk melindungi kepentingan anak. Perhatian dan perlakuan khusus tersebut berupa perlindungan hukum agar anak tidak menjadi korban dari penerapan hukum yang salah yang dapat menyebabkan penderitaan mental, fisik dan sosialnya. Perlindungan anak pelaku tindak pidana dalam proses penyidikan berdasarkan Undang-Undang Nomor 11 Tahun 2012 dilakukan oleh Penyidik anak yang ditetapkan berdasarkan Keputusan Kepala Kepolisian Negara Republik Indonesia atau pejabat lain yang ditunjuk oleh Kepala Kepolisian Negara Republik Indonesia. Pelaksanaan penyidikan terhadap anak pelaku tindak pidana dalam proses penyidikan meliputi tindakan penangkapan, pemeriksaan, penghentian penyidikan dan penahanan.

\section{SARAN}

Diharapkan perlunya pemberian pemahaman kepada anak sebagai pelaku tindak pidana anak mengenai hak-haknya dalam hal perlindungan hukum berdasarkan ketentuan peraturan perundang-undangan yang berlaku, sehingga dapat mengurangi terjadinya pelanggaran dalam perlindungan hukum terhadap hak anak sebagai pelaku tindak pidana anak. 


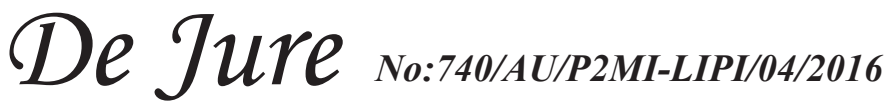

\section{DAFTAR KEPUSTAKAAN}

Allen, Steven, Kata Pengantar, dalam Purnianti, Mamik Sri Supatmi, dan Ni Made Martini Tinduk, Analisa Situasi Sistem Peradilan Pidana Anak (Juvenile Justice System) di Indonesia, UNICEF, Indonesia, 2003

Adenwalla, Ms. Maharukh, Child Protection and Juvenile Justice System : for Juvenile inConflict with Law, CHILDLINE India Foundation, Mumbai, 2006.

Hadisuprapto, Paulus, Juvenile Delinquency Pemahaman dan Penanggulangannya, PT. Citra Aditia Bakti, Bandung, 1997.

Marlina, Peradilan Pidana Anak di Indonesia, Pengembangan Konsep Diversi dan Restorative justice, Bandung, Refika Aditama 2009,

Rochaeti, Nur, "Model Restorative Justice sebagai Alternatif Penanganan bagi Anak Delinkuen di Indonesia", MMH Jilid 37 No. 4, Desember, Tahun 2008.

Soerjono Soekanto, Sebab Musabab dan Pemecahanya Remaja dan Masalahnya ,Kanisius, Yogyakarta, 1982,

Yayasan Pemantau Hak Anak, Praktek-Praktek Penanganan Anak Berkonflik dengan Hukum Dalam Kerangka Sistem Peradilan Pidana Anak (Juvenile Justice System) Di Indonesia: Perspektif Hak Sipil dan Hak Politik, tanpa tahun.

\section{Peraturan Perundang-Undangan:}

Indonesia, Undang-Undang Nomor 23 Tahun 2002 Tentang Perlindungan Anak, Lembaran Negara No. 109, Tambahan Lembaran Negara No. 4235.

Indonesia, Undang-Undang Nomor 11 Tahun 2012 Tentang Sistem Peradilan Pidana Anak. Lembaran Negara No. 153, Tambahan Lembaran Negara No. 5332.

Indonesia, UndangUndang No. 8 Tahun 1981 tentang Kitab Undang-Undang Hukum Acara Pidana(KUHAP)..

Keputusan Presiden No. 36 tahun 1990 Tentang Pengesahan Konvensi Hak Anak, 


\section{De JuYe akreditasi LIPI: No:740/AU/P2MI-LIPI/04/2016}

\section{BIODATA PENULIS}

Nama, Rosmi Darmi, S.H., M.H., tempat \& tanggal lahir, Solok 6 Oktober 1954, Jbatan Fungsikonal Peneliti Hukum Pada Pusat Penelitian dan Pengembangan Hukum Badan Penelitian dan Pengembangan Hukum dan Ham Kementerian Hukum RI, Pendidikan Strata -1 dari UNIS Tangerang. Magister Hukum Sekolah Tinggi nIlmu Hukum - IBLAM, Jakarta Tahun 2002. Alamt Ruuamah Jl. Veteran Raya Blok 12 No. 9, Tangerang. Telpon 0215580811 


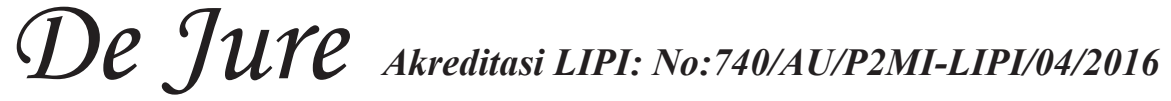

\section{PEDOMAN PENULISAN NASKAH JURNAL PENELITIAN HUKUM DE JURE}

1. Naskah yang dimuat dalam Jurnal Penelitian Hukum De Jure adalah tulisan yang belum pernah dipublikasikan dalam media massa.

2. Naskah yang dimuat dalam Jurnal Penelitian Hukum De Jure meliputi tulisan tentang hasil penelitian (penelitian empiris maupun penelitian normatif atau studi dokumenter), pemikiran dan informasi lain yang bersifat ilmiah.

3. Menggunakan bahasa Indonesia yang baku.

4. Sistimatika Penulisan :

A. Naskah artikel hasil penelitian empiris :

o Judul aktual

Menggambarkan isi naskah dan maksimal 14 kata ditulis dalam bahasa Indonesia dan Inggris

o Nama penulis

Tanpa gelar akademik, jabatan, kepangkatan, alamat lembaga/instansi dan e-mail

o Abstrak

Berisi Latar Belakang, Rumusan Masalah, Tujuan, Kegunaan, Metode, Isi

Pembahasan, Analisis, Kesimpulan dan Saran Temuan ditulis dalam satu spasi;

150 kata (10-20 baris/ satu (1) paragraf) diketik menggunakan huruf Times New

Roman; font 11 italic; ditulis dalam bahasa Indonesia dan bahasa Inggris.

o Kata Kunci

Mengandung yang di indekskan ditulis dalam bahasa Indonesia dan Inggris

dengan minimal 3 kata maksimal 5 kata

- PENDAHULUAN

Berisi latar belakang masalah dan rumusan masalah, tujuan, kegunaan, kerangka Teori/Konsep, Metode (metode penelitian yang digunakan, di antaranya meliputi jenis penelitian, lokasi penelitian, sumber data, teknik pengumpulan data, pengolahan data dan analisis data.)

- PEMBAHASAN

Berisi, pembahasan terhadap masalah yang diteliti

- Analisis

Berisi analisis dari semua pokok pembahasan

- PENUTUP

Kesimpulan dan saran

Kesimpulan dan saran ditulis dalam bentuk uraian bukan dalam bentuk'angka

- DAFTAR KEPUSTAKAAN

Daftar Pustaka : ditulis berdasarkan abjad, dengan urutan : Nama pengarang. Judul buku. Kota penerbit: nama penerbit, tahun penerbitan.

Contoh ....Hamzah. Andi, Bantuan Hukum suatu Tinjauan Yuridis. Ghalia

Indonesia, Jakarta, 1983. 


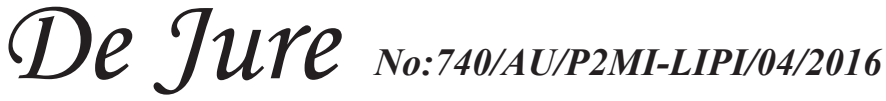

B. Naskah artikel ulasan Hasil penelitian normatif atau studi dokumenter), pemikiran dan informasi lain yang bersifat ilmiah.

o Judul aktual

Menggambarkan isi naskah dan maksimal 14 kata ditulis dalam bahasa

Indonesia dan Inggris

o Nama penulis

Tanpa gelar akademik, jabatan, kepangkatan, alamat lembaga/instansi dan e-mail

o Abstrak

Berisi Latar Belakang, Rumusan Masalah, Tujuan, Kegunaan, Metode, Isi

Pembahasan, Analisis, Kesimpulan dan Saran Temuan ditulis dalam satu spasi;

150 kata (10-30 baris/ satu (1) paragraf) diketik menggunakan huruf Times

New Roman; font 11 italic; ditulis dalam bahasa Indonesia dan bahasa Inggris

o Kata Kunci

Mengandung yang di indekskan ditulis dalam bahasa Indonesia dan Inggris

minimal 3 kata maksimal 5 kata

- PENDAHULUAN

Latar belakang masalah dan rumusan masalah

- PEMBAHASAN

Berisi, pembahasan terhadap masalah yang dikaji

- ANALISIS

Berisi analisis dari semua pokok pembahasan

- PENUTUP

Kesimpulan Dan Saran

Kesimpulan dan saran ditulis dalam bentuk uraian bukan dalam bentuk angka

- DAFTAR KEPUSTAKAAN

Daftar Pustaka : ditulis berdasarkan abjad, dengan urutan : Nama pengarang. Judul buku. Kota penerbit : nama penerbit, tahun penerbitan.

Contoh ....Hamzah. Andi, Bantuan Hukum suatu Tinjauan Yuridis. Ghalia

Indonesia, Jakarta, 1983.

5. Naskah dilengkapi dengan indeks.

6. Naskah diketik rapi 1,5 spasi di atas kertas A4; menggunakan huruf Times New Roman; Font 11; antara 20-30 halaman; diprint out dan disertai soft copy CD.

7. Penulisan kutipan sumber rujukan dengan sistem bodynote, yaitu menulisk ${ }^{\wedge} \mathrm{n}$ nama pengarang (tanpa gelar akademik); tahun penerbitan dan no halaman, yang ditulis dalam kurung; diletakan dibelakang kutipan. Contoh : .(Hamzah, 2007: 15)

8. Isi tulisan di luar tanggungjawab redaksi. Dan redaksi berhak mengedit redaksional tanpa merubah arti.

9. Naskah yang belum memenuhi syarat akan dikonfirmasikan atau dikembalikan untuk diperbaiki.

10. Keterangan lengkap dapat menghubungi redaksi Jurnal Peneltian Hukum De Jure melalui Email: jurnaldejure@yahoo.com 
